\title{
THE EFFECT OF SERVICE QUALITY APPLICATION BASED OF CAPSULE TRANS BUS JAMBI CITY ON CUSTOMER LOYALTY THROUGH CUSTOMER SATISFACTION AS AN INTERVENING VARIABLE
}

\author{
Dwi Kurniawan ${ }^{1}$, Feny Tialonawarmi ${ }^{2}$, Ade Titi Nifita ${ }^{3}$ \\ 1,2,3 Faculty of Economics and Business, Universitas Jambi \\ Corresponding author: dwi.kurniawan13@unja.ac.id,
}

\begin{abstract}
Digitalization in the transportation sector is a necessity. At the same time, several cities in Indonesia have already carried the concept of a smart city. Jambi city government launched the Kota Trans Capsule Bus, the first application based bus in Indonesia. The capsule bus's presence is an innovation in public transportation with comfortable, modern, high technology and supports Jambi as a smart city in Indonesia. The purpose of this study was to examine and analyze the effect of service quality application based on Capsule Trans City Bus on customer loyalty through customer satisfaction as an intervening variable. The analysis test tool used is SmartPLS v.3.3.0 and use the SEM (Structural Equation Model) analysis method. The results showed that the coefficient of indirect paths through the variable (I) customer satisfaction with a value of 0.662 is greater than the path coefficient of 0.075. this means that the application-based trans-Jambi City Capsule Bus's service quality affects customer loyalty but non-directly, namely through the intervening variable customer satisfaction. It means that customer satisfaction mediates between the influence of service quality on customer loyalty.
\end{abstract}

Keywords: Service Quality; Customer Satisfaction; Customer Loyalty; Application based.

\section{Introduction}

In the modern era, people generally have a kind of activity that is mobile and dynamic. People can use transportation services to travel to other places, which further impacts transportation needs by land, sea, or air.

Several cities in Indonesia, including Jambi City Government, have adopted the smart city concept. The government launched an application based on Capsule Trans Bus Jambi City by supporting the smart city concept. The Capsule Trans Jambi City's existence is a public innovation that is comfortable, modern, and high-tech, that it can affect customer satisfaction.

The service provided by Capsule Trans Jambi City is technology-based. To get on the bus, we must first download or install the "Capsule Bus" application on Google Play. Secondly, we have to fill in our data in the form of an email address and an active phone number. We can then use the application to book a bus following the pic-up location point that we have set on the app.

This system can make generally easy to use by some people, and others also find them difficult. Therefore, this phenomenon must be investigated how the service quality provided by the application-based capsule trans bus Jambi City towards customer satisfaction and its customers' loyalty. The big question of these customers to repeat to use capsule trans bus Jambi City or not. Therefore, in this study, the researcher interesting in examining "the effect of service quality of application-based capsule trans bus Jambi City on customer loyalty through customer satisfaction as an intervening variable.

\section{Research Problems}

The research of the problems in this study, namely:

1. How does the service quality of application-based capsule trans bus Jambi City affect customer loyalty?

2. How does the service quality of application-based capsule trans bus Jambi City affect customer satisfaction?

3. How does customer satisfaction affect customer loyalty to the quality of application-based capsule trans bus Jambi City?

4. How does application-based capsule trans bus Jambi City's service quality on customer loyalty through customer satisfaction as an intervening variable?

\section{Research objectives}

1. To examine and analyze the effect of service quality of the application based capsule trans bus Jambi City on customer loyalty.

2. To examine and analyze the effect of service quality of the application based capsule trans bus Jambi City on customer satisfaction 
3. To examine and analyze the effect of customer satisfaction with the application based capsule trans bus Jambi City

4. To examine and analyze service quality, the application-based capsule trans bus Jambi City on customer loyalty through customer satisfaction as an intervening variable.

\section{Literature Review}

\section{Service Quality}

Kotler and Keller (2009:143) show that "Quality is the totality of features and characteristics of a product or service that depends on its ability to satisfy stated or implied needs." Service quality is a strategy carried out by companies to display products or services that reference achieving sustainable excellence, either as a market leader or a strategy to continue developing (Mardikawati,2013). Service quality is the company's ability to meet its existing service needs to achieve an advantage over its competitors.

Mardikawati and Farida (2013), the indicators that measure customer satisfaction in transportation services, namely: the existence of service conformity with the expected rate, the existence of service conformity with rates paid, customer satisfaction with the service offered.

\section{Customer Loyalty}

According to Kotler and Keller (2012:207), "loyalty is a firmly held commitment to repurchasing or subscribing to selected products or services in the future even though situational influences and marketing efforts have the potential to cause consumers to switch to other products." Customer loyalty to the products or services we provide will make customers want to subscribe or repeat using the services.

Griffin (2003:113) shows customer loyalty when customers show their tendency to use the services or products they have used as indicators in measuring customer loyalty, namely: to repurchase regularly, repeat, and customer make decisions to make purchases continuously. Persistently against purchases outside the line of products and services, referencing others, showing invulnerability against competitors.

\section{Research Methods}

This research objectifies the quality service of the Capsule Bus Trans City Jambi service, customer satisfaction, and customer loyalty. The population in this study are customers who use the Capsule Bus Trans City Jambi service. The number of samples or respondents with a total population that is 4 to 8 times the number of indicators studied, the researchers took five times the indicators of this study. In this study, the data collection methods used were observation, interview, and questionnaire methods.

The methods of data analysis in this study using smartPLS v.3.3. the PLS (partial least square) method, the analysis techniques used are the outer model analysis and the internal model analysis. Also, in this research method, an analysis of the direct effect, indirect effect, and total effect will be analyzed.

\section{Results \\ Respondent Profile}

In this study, to explain the profile characteristics of the 66 respondents, the researcher described them based on the criteria of gender, age, occupation, latest education, and daily used transportation. The following is an explanation of the various characteristics of respondents who use the service quality of application-based capsule bus trans Jambi city.

Table 1. Respondent characteristics profile

\begin{tabular}{|l|l|l|c|}
\hline No & \multicolumn{1}{|c|}{ Respondent characteristics } & \multicolumn{1}{c|}{ Respondent } & percentage \\
\hline 1 & Gender & Female & $53.07 \%$ \\
\hline 2 & Age & $18-27$ y.o & $72.72 \%$ \\
\hline 3 & Job & Student & $65.15 \%$ \\
\hline 4 & Last education & Senior High School & $59.09 \%$ \\
\hline 5 & Daily transportation & Private & $86,36 \%$ \\
\hline
\end{tabular}

Source: Research Survey Data 2020

\section{The Outer Model}

An indicator is valid if it has a loading factor above 0.5 against the intended construct. The SmartPLS output in this study for the loading factor gives the following results: 


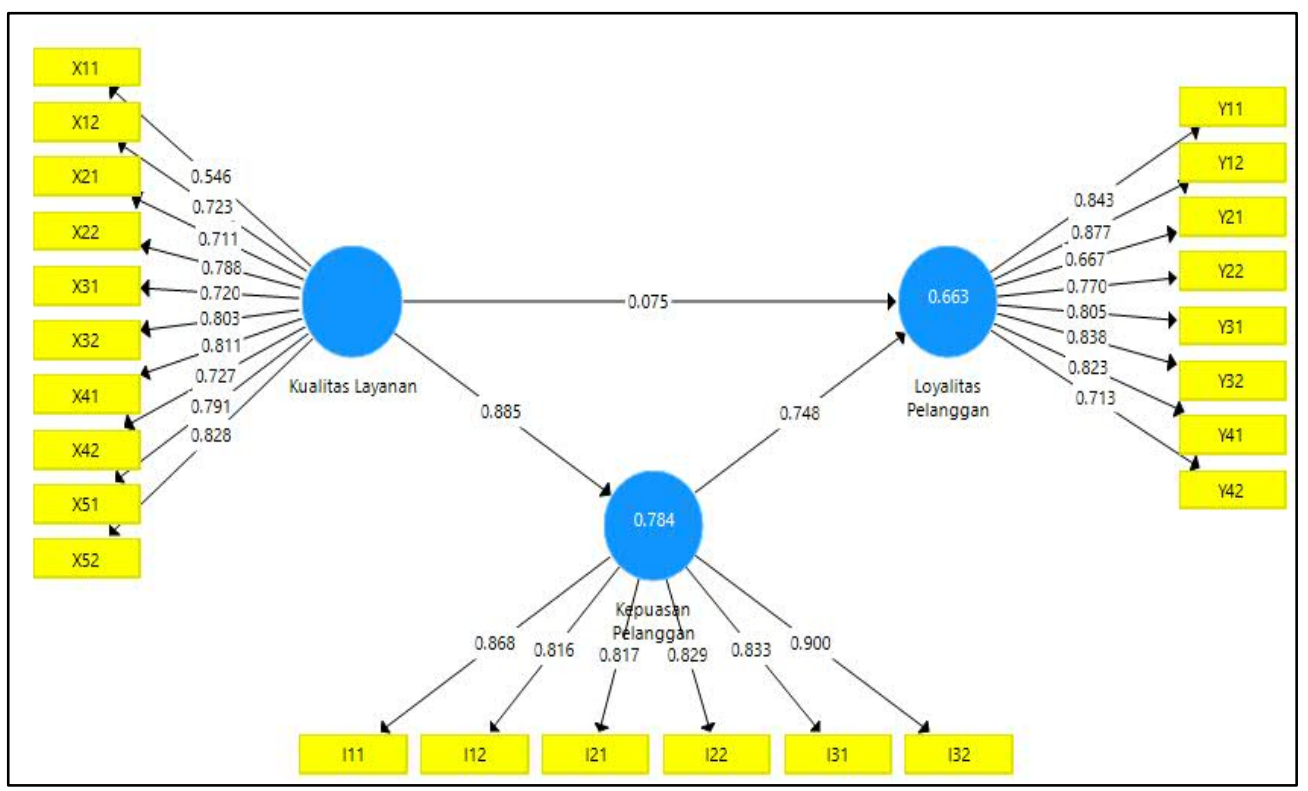

Figure 1: PLS Model

Figure 1 shows that the level of validity with a correlation test between each item's score and the total score shows a positive and significant correlation at the level of $5 \%$ or above 05 . It means that the indicators used in this study are valid or have met the convergent validity.

\section{Data Reliability Test}

The reliability test is done using the composite reliability value of the indicator block that measures the construct. The result of composite reliability will show a good value if it is above 0.7 . reliability testing can also be strengthened with Cronbach's Alpha. The SmartPLS output gives the following results.

Table 2. Cronbach's Alpha dan Composite Reliability

\begin{tabular}{|l|c|c|}
\hline Variable & $\begin{array}{c}\text { Cronbach's } \\
\text { Alpha }\end{array}$ & $\begin{array}{c}\text { Composite } \\
\text { Reliability }\end{array}$ \\
\hline Customer Satisfaction & 0,919 & 0,937 \\
\hline Quality Service & 0,911 & 0,927 \\
\hline Customer Loyalty & 0,915 & 0,932 \\
\hline
\end{tabular}

Source: processed data with SmartPLS, 2020

Based on table 3, it can be seen that $\mathrm{R}$ square gives a value of 0.784 for the customer satisfaction construct, which means that service quality (x) affects customer satisfaction (I) by $78.84 \%$, while for the customer loyalty construct it gives a value of 0.663 which means that service quality (X) and customer satisfaction (I) affect customer loyalty (Y) by $66.3 \%$.

\section{Direct Effect}

There is a direct or significant effect if the $\mathrm{p}$-value is $<0.05$, and it is said there is no direct or insignificant effect if the p-value is $>0.05$.

Table 3. (Direct Effect)

\begin{tabular}{|l|c|c|c|c|c|}
\hline & $\begin{array}{c}\text { Original } \\
\text { Sample } \\
(\mathbf{O})\end{array}$ & $\begin{array}{c}\text { Sample } \\
\text { Mean } \\
(\mathbf{M})\end{array}$ & $\begin{array}{c}\text { Standard } \\
\text { Deviation } \\
\text { (STDEV) }\end{array}$ & T Statistics & P-value \\
\hline $\begin{array}{l}\text { Customer Satisfaction -> } \\
\text { Customer Loyalty }\end{array}$ & 0,748 & 0,755 & 0,111 & 6,714 & 0,000 \\
\hline $\begin{array}{l}\text { Quality Service -> Customer } \\
\text { Satisfaction }\end{array}$ & 0,885 & 0,888 & 0,028 & 31,835 & 0,000 \\
\hline $\begin{array}{l}\text { Quality Service -> Customer } \\
\text { Loyalty }\end{array}$ & 0,075 & 0,075 & 0,124 & 0,604 & 0,546 \\
\hline
\end{tabular}

Source: processed data with SmartPLS, 2020

Based on table 3. the statement is as follows: 
a. The Customer Satisfaction variable has a significant positive effect on the Customer Loyalty variable with the t-statistics value $(6,714)>$ of the t-table $(1.96)$ and the $p$-value $0,000<0.05$.

b. The Service Quality variable has a significant positive effect on the Customer Satisfaction variable with the t-statistics value (31.835)> from the t-table (1.96) and p-value $0.000<0.05$.

c. The Service Quality variable has a positive but insignificant effect on the Customer Loyalty variable with the t-statistics value (0.604) <from the t-table (1.96) and the p-value 0.546>0.05.

\section{Indirect Effect}

If the P-Value $<0.05$ is significant, it means the mediator variable mediates an exogenous variable's effect on an endogenous variable. In other words, the effect is indirect. If the P-Value> 0.05 is not significant, it means the mediator variable does not mediate an exogenous variable's effect on an endogenous variable. In other words, the effect is direct.

Table 4. Indirrect Effect

\begin{tabular}{|l|c|c|c|c|c|}
\hline & $\begin{array}{c}\text { Original } \\
\text { Sample } \\
(\mathbf{O})\end{array}$ & $\begin{array}{c}\text { Sample } \\
\text { Mean } \\
(\mathbf{M})\end{array}$ & $\begin{array}{c}\text { Standard } \\
\text { Deviation } \\
\text { (STDEV) }\end{array}$ & T Statistics & value \\
\hline $\begin{array}{l}\text { Quality Service -> } \\
\begin{array}{l}\text { Customer Satisfaction -> } \\
\text { Customer Loyalty }\end{array}\end{array}$ & 0,662 & 0,671 & 0,107 & 6,211 & 0,000 \\
\hline
\end{tabular}

Source: processed data with SmartPLS, 2020

Based on table 4, the indirect effect of Service Quality -> Customer Satisfaction -> Customer Loyalty is 0.662 with a P-Value of $0.000<0.05$, which means the customer satisfaction variable significantly mediates the influence of the Service Quality variable on Customer Loyalty.

\section{Total Effect}

Table 5. Total Effect

\begin{tabular}{|l|c|c|c|c|c|}
\hline & $\begin{array}{c}\text { Original } \\
\text { Sample } \\
(\mathbf{O})\end{array}$ & $\begin{array}{c}\text { Sample } \\
\text { Mean } \\
(\mathbf{M})\end{array}$ & $\begin{array}{c}\text { Standard } \\
\text { Deviation } \\
\text { (STDEV) }\end{array}$ & $\begin{array}{c}\text { T } \\
\text { Statistics }\end{array}$ & P-Value \\
\hline $\begin{array}{l}\text { Customer Satisfaction -> } \\
\text { Customer Loyalty }\end{array}$ & 0,748 & 0,755 & 0,111 & 6,714 & 0,000 \\
\hline $\begin{array}{l}\text { Quality Service -> Customer } \\
\text { Loyalty }\end{array}$ & 0,885 & 0,888 & 0,028 & 31,835 & 0,000 \\
\hline $\begin{array}{l}\text { Quality Service -> Customer } \\
\text { Loyalty }\end{array}$ & $\mathbf{0 , 7 3 7}$ & $\mathbf{0 , 7 4 6}$ & $\mathbf{0 , 0 7 9}$ & $\mathbf{9 , 3 5 6}$ & $\mathbf{0 , 0 0 0}$ \\
\hline
\end{tabular}

Source: processed data with SmartPLS, 2020

Based on table 5, the total effect (Total Effect) has an at-statistics value of 9.356> t-table 1.96, which means that service quality influences customer loyalty but not directly, namely through the intervening variable customer satisfaction. It means that customer satisfaction mediates between the influence of service quality on customer loyalty.

\section{Discussion}

The effect of service quality of application-based capsule trans bus Jambi City on customer loyalty.

Data analysis results show that the service quality of the application-based capsule bus Jambi City Trans influences customer loyalty but not directly. The application-based Jambi city of bus capsule service quality cannot directly affect customer loyalty. Even though the quality of service is considered acceptable in customers' eyes, it does not necessarily affect the formation of loyalty directly to a product or service.

Any technology activity can be applied, but not everyone is easy to apply thin technological sophistication. This research proves that even a comfortable, modern, high-tech, and good service quality cannot directly affect customer loyalty. Customers will be loyal when they are satisfied with the services provided.

The effect of service quality of the application based capsule trans bus Jambi City on customer satisfaction

Data analysis results show that the service quality of the application-based Capsule Bus Jambi City Trans has a significant positive effect on customer satisfaction. These results indicate that if the quality of service is good, customer satisfaction will increase. This explains that the better the Jambi trans city capsule bus customers' quality of service, the better the Jambi trans city bus capsule service's assessment to increase customer satisfaction. 
The effect of customer satisfaction with the application based capsule trans bus Jambi City

Data analysis results show that customer satisfaction with the Application-Based Capsule Trans Bus Jambi City has a significant positive effect on customer loyalty. These results indicate that the higher the customer satisfaction of the Capsule Trans Bus Jambi City is obtained, the higher the customer loyalty level will be carried out by customers in the future.

This study's results are consistent with other research conducted by Trisno Musanto (2004) on "Factors of Customer Satisfaction and Customer Loyalty: Case Studies at CV. Sarana Media Advertising Surabaya). The results showed that customer satisfaction has a positive and significant effect on customer loyalty.

The effect of service quality on the application based capsule trans bus Jambi City on customer loyalty through customer satisfaction as an intervening variable.

The data results show that the customer satisfaction variable significantly mediates the effect of the service quality variable on customer loyalty. These results indicate that if the service quality of the Capsule Trans Bus Jambi City is improved, it will encourage an increase in customer satisfaction and an impact on increased customer loyalty.

This study shows that service quality affects customer loyalty but not directly through the intervening variable customer satisfaction. This is based on the indirect path coefficient's value through the customer satisfaction variable, which has a value of 0.662 , which is greater than the direct path coefficient of 0.075 . It means that customer satisfaction mediates between the influence of service quality on customer loyalty.

\section{Conclusion}

This study examines and analyzes the effect of the application-based service quality of the Capsule Trans Bus Jambi City on customer loyalty through customer satisfaction as an intervening variable. The following are the conclusions of the results of the description in this study:

1. The quality service of application-based Capsule Trans Bus Jambi City s has a positive but insignificant effect on customer loyalty

2. The quality service of application-based Capsule Trans Bus Jambi City has a significant positive effect on customer satisfaction

3. The effect of customer satisfaction has a significant positive effect on customer loyalty of the applicationbased capsule bus in Jambi

4. The effect of application-based capsule bus service quality on customer loyalty through customer satisfaction as an intervening variable shows that service quality influences customer loyalty but not directly, namely through the intervening variable customer satisfaction. It was based on the indirect path coefficient's value through the customer satisfaction variable, which has a value of 0.662 , more significant than the direct path coefficient of 0.075 . It means that customer satisfaction mediates the effect of service quality on customer loyalty.

\section{Suggestion}

In this study, it shows that service quality has an influence on customer loyalty but not directly through the intervening variable customer satisfaction. The quality of service affects customer loyalty more indirectly than the direct effect. Therefore, the quality of the application-based capsule trans bus Jambi City service must be improved again to make customers loyal without having to have any intervening variables such as customer satisfaction.

\section{References}

Augusty Ferdinand. 2011. Metode Penelitian Manajemen Pedoman Penelitian untuk Penulisan Skripsi, Tesis, dan Disertasi Ilmu Manajemen, Edisi 3, AGF Books, Fakultas Ekonomika dan Bisnis Universitas Diponegoro, Semarang.

Azwar, S. 2005. Metode Penelitian. Yogyakarta : Pustaka Pelajar

Ghozali, Imam. 2009. Aplikasi Analisis Multivariate dengan Program SPSS. Semarang: Badan Penerbit Universitas Diponegoro.

Ghozali, Imam. 2011. Aplikasi Analisis Multivariate Dengan Program Spss 19. Semarang: Badan Penerbit Universitas Diponegoro

Griffin, Jill. 2003. Customer Loyalty: Menumbuhkan Dan Mempertahankan Pelanggan. Penerbit Erlangga. Jakarta

Irawan, Handy. 2002. 10 Prinsip Kepuasan Pelanggan. Jakarta: PT Elex Media

Kiki Amelia. 2016. Pengaruh Kualitas Layanan terhadap Loyalitas Pelanggan melalui Kepuasan Pelanggan sebagai Variabel Intervening (Studi pada Pelanggan Dunkin Donuts di Surabaya dan Sidoarjo). Jurnal Bisnis dan Manajemen Vol.9 No. 1 
Kotler, Philip dan Keller, Kevin Lane. 2009. Edisi ketiga belas. Jilid 1. Manajemen Pemasaran. Terjemahan oleh Bob Sabran MM. Jakarta: Erlangga.

Kotler, P dan Kevin Lane Keller. 2012. Manajemen Pemasaran, Edisi Ketiga Belas Judul 1. Jakarta : Erlangga Lupiyoadi, Hamdani. 2006. Manajemen Pemasaran. Edisi Kedua. Jakarta: Salemba Empat.

Malhotra, N.K., dan Birks, D.F. 2007. Marketing Research: An Applied Orientation (3rd European Edition ed.). Harlow: Prentice-Hall.

Mardikawati, Woro dan Farida, Naili. 2013. Pengaruh Nilai Pelanggan dan Kualitas Layanan Terhadap Loyalitas Pelanggan, Melalui Kepuasan Pelanggan pada Pelanggan Bus Efisiensi. Jurnal Administrasi Bisnis. Semarang: UNDIP.

Mas'ud, Fuad. 2004. Survai Diagnosis Organisasional Konsep \& Aplikasi. Badan Penerbit Universitas Diponegoro. Semarang.

Molden, Srikandi dan Edy. 2014. Pengaruh Kualitas Pelayanan terhadap Kepuasan, Kepercayaan dan Loyalitas (Survei pada Pelanggan yang Menginap di Jambuluwuk Batu Resort Kota Batu). Jurnal Administrasi Bisnis (JAB) Vol. 15 No. 2

Musanto, Trisno. 2004. Faktor-Faktor Kepuasan Pelanggan dan LoyalitasPelanggan: Studi Kasus pada CV. Sarana Media Advertising Surabaya. Jurnal Ekonomi Manajemen. Vol. 6, No. 2: 123-136.

Sugiyono. 2012. Metode Penelitian Kuantitatif, Kualitatif dan R\&D Bandung : Alfabeta.

Tjiptono, Fandy dan Chandra, Gregorius. 2012. Pemasaran Strategik.Andi:Yogyakarta. 